\title{
RNA-sequencing reveals the complexities of the transcriptional response to lignocellulosic biofuel substrates in Aspergillus niger
}

Steven T Pullan ${ }^{1,4 \dagger}$, Paul Daly ${ }^{1 \dagger}$, Stéphane Delmas ${ }^{1,5}$, Roger lbbett $^{2}$, Matthew Kokolski ${ }^{1}$, Almar Neiteler ${ }^{1}$, Jolanda M van Munster ${ }^{1}$, Raymond Wilson ${ }^{3}$, Martin J Blythe ${ }^{3}$, Sanyasi Gaddipati ${ }^{2}$, Gregory A Tucker ${ }^{2}$ and David B Archer ${ }^{1 *}$

\begin{abstract}
Background: Saprobic fungi are the predominant industrial sources of Carbohydrate Active enZymes (CAZymes) used for the saccharification of lignocellulose during the production of second generation biofuels. The production of more effective enzyme cocktails is a key objective for efficient biofuel production. To achieve this objective, it is crucial to understand the response of fungi to lignocellulose substrates. Our previous study used RNA-seq to identify the genes induced in Aspergillus niger in response to wheat straw, a biofuel feedstock, and showed that the range of genes induced was greater than previously seen with simple inducers.

Results: In this work we used RNA-seq to identify the genes induced in A. niger in response to short rotation coppice willow and compared this with the response to wheat straw from our previous study, at the same time-point. The response to willow showed a large increase in expression of genes encoding CAZymes. Genes encoding the major activities required to saccharify lignocellulose were induced on willow such as endoglucanases, cellobiohydrolases and xylanases. The transcriptome response to willow had many similarities with the response to straw with some significant differences in the expression levels of individual genes which are discussed in relation to differences in substrate composition or other factors. Differences in transcript levels include higher levels on wheat straw from genes encoding enzymes classified as members of GH62 (an arabinofuranosidase) and CE1 (a feruloyl esterase) CAZy families whereas two genes encoding endoglucanases classified as members of the GH5 family had higher transcript levels when exposed to willow. There were changes in the cocktail of enzymes secreted by A. niger when cultured with willow or straw. Assays for particular enzymes as well as saccharification assays were used to compare the enzyme activities of the cocktails. Wheat straw induced an enzyme cocktail that saccharified wheat straw to a greater extent than willow. Genes not encoding CAZymes were also induced on willow such as hydrophobins as well as genes of unknown function. Several genes were identified as promising targets for future study.

Conclusions: By comparing this first study of the global transcriptional response of a fungus to willow with the response to straw, we have shown that the inducing lignocellulosic substrate has a marked effect upon the range of transcripts and enzymes expressed by A. niger. The use by industry of complex substrates such as wheat straw or willow could benefit efficient biofuel production.
\end{abstract}

Keywords: Biofuels, RNA-seq, Aspergillus, Wheat straw, Willow, Transcriptome

\footnotetext{
* Correspondence: david.archer@nottingham.ac.uk

${ }^{\dagger}$ Equal contributors

'School of Life Sciences, University of Nottingham, University Park,

Nottingham NG7 2RD, UK

Full list of author information is available at the end of the article
}

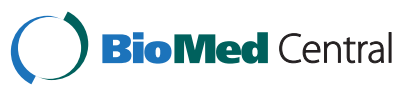

(c) 2014 Pullan et al.; licensee BioMed Central Ltd. This is an Open Access article distributed under the terms of the Creative Commons Attribution License (http://creativecommons.org/licenses/by/4.0), which permits unrestricted use, distribution, and reproduction in any medium, provided the original work is properly credited. The Creative Commons Public Domain Dedication waiver (http://creativecommons.org/publicdomain/zero/1.0/) applies to the data made available in this article, unless otherwise stated. 


\section{Background}

The production of second generation biofuels uses lignocellulose as the source of sugars for fermentation [1]. A key problem with using lignocellulose is its recalcitrance to saccharification. This recalcitrance leads to a requirement for large amounts of polysaccharide-degrading enzymes which are costly to produce at the industrial scale. Furthermore, the enzyme cocktails produced mainly by saprobic fungi are usually deficient in activities required for complete saccharification of a particular substrate. One cause of this may be the industrial use of simple, cost effective inducers, such as lactose or cellulose which fail to induce the full range of hydrolytic and accessory activities encoded within an organism's genome. Differences in the enzyme cocktails expressed in response to complex, lignocellulosic substrates as compared to defined substrates such as pure cellulose have been observed in several fungal species [2-5]. Simple inducers may not provide the most effective possible enzyme profile that is achievable from the arsenal encoded within a fungal genome for any given substrate. The effectiveness of the cocktail is also likely to vary towards different substrates, even if the induction mechanism remains elusive. The pairing of inducer and lignocellulosic substrate is therefore a key consideration in biofuel production.

The perspective of how plants and fungi evolved provides a context for improvement of the efficiency of saccharification. Lignocellulose is present in plant secondary cell walls and is mainly composed of cellulose, hemicelluloses and lignin [1]. Generally, plants that are evolutionarily close share a more similar lignocellulose composition and this is particularly evident in hemicellulose composition [6]. At the same time, fungi have evolved complex regulatory mechanisms to sense their environment including nutrients such as lignocellulose [7]. This is evidenced by the response of fungi to the presence of different polysaccharides such as xylan, arabinan or pectin and suggests that fungi may have specific degradative responses to lignocellulosic substrates from different plant species [8].

We chose to study the response of a fungus to two plant species using Aspergillus niger as the fungus and wheat (Triticum aestivum) and willow (Salix sp.) as the plant species for three key reasons. Firstly, wheat (a grass) and willow (a tree) represent the two major lineages of flowering plants which have evolved cell walls with diverse compositions. Secondly, both species are of potential industrial relevance as feedstocks for biofuel production [9]. Thirdly, A. niger is an industrially-relevant model fungus with a large repertoire of CAZymes [10]. Recent studies have highlighted the potential of $A$. niger to respond differently at the transcriptional level to different polysaccharides $[5,11]$ making it ideally suited to investigate responses to different substrates.
RNA-seq is a method which is transforming how transcriptomes are studied [12] and provides a highly sensitive read-out of responses to substrates at the genome-wide level. Our previous studies using RNA-seq have defined and compared the responses of $A$. niger and T. reesei to wheat straw $[5,13,14]$. Another study by Hakkinen et al. [3], in T. reesei showed differences and similarities in the transcriptional response to different lignocellulosic substrates. One limitation of that and other studies is the use of microarrays which have a narrower range for which expression can be measured compared to RNA-seq. Also, substrates can be used that have been subjected to harsh pre-treatments, albeit industrially relevant, which alter the substrate far from what fungi have evolved to sense and degrade in nature.

To our knowledge, there is no study that reports the transcriptional response of a fungus to willow, a perennial species that has much potential as a bioenergy crop [9]. The use of the same experimental conditions for culturing A. niger on straw and willow presented a unique opportunity to compare the transcriptional responses of $A$. niger to these substrates. These transcriptional responses were compared with biochemical assays of the protein mixes secreted by $A$. niger when cultured with the different substrates.

Here we report on differences and similarities in the transcriptional responses and the secreted protein activities of $A$. niger exposed to wheat straw or willow. We show that the fungal response is to some extent specific to the inducing substrate. Moreover, our results highlight the importance of using complex inducing substrates for production of enzymes and accessory proteins by industry or for discovering the relevant small inducing molecules. Finally, we discuss how biotechnology could be used to benefit biofuels by making better fungal strains.

\section{Results and discussion}

\section{The willow-induced CAZy expression profile}

A. niger was cultured in a glucose medium for $48 \mathrm{~h}$ followed by transfer to a medium where ball-milled willow was the sole carbon source for $24 \mathrm{~h}$. The sugar composition of the willow substrate (as \% of total solids) was $38.5 \%( \pm 0.90)$ glucose, $10.4 \%( \pm 1.03)$ xylose and $1.1 \%$ arabinose $( \pm 0.02)$ and the lignin content was $23.1 \%$ $( \pm 0.95)$ (the values in parentheses are standard deviations). To re-introduce a simple carbon source in the presence of lignocellulose, glucose was added to the willow cultures after $24 \mathrm{~h}$ and incubated for a further $5 \mathrm{~h}$. RNA was extracted and sequenced from these three conditions. Reads including those mapping to genes encoding enzymes defined by CAZy $[15,16]$ as being either glycoside hydrolases, polysaccharide lyases, carbohydrate esterases or auxiliary activity proteins, were counted and the relative expression of each family was calculated. 
Figure 1 shows that after culturing $A$. niger for $24 \mathrm{~h}$ with willow, the most abundantly expressed family is GH5, which accounts for $13.3 \%$ of total CAZy RPKM (Reads Per Kilobase per Million mapped reads). The GH5 family is divided into a range of subfamilies and encompasses a variety of functions [17]. The majority of GH5 family expression seen in this study originates from two endoglucanaseencoding genes, TID_205580 and TID_209376 (eglB), which are expressed at 121 and 210 RPKM respectively. The expression values of the genes described in this section are listed in Table 1 and a full list of individual gene expression values can be found in the Additional file 1.

The two GH7, reducing-end-active, cellobiohydrolases encoded within the $A$. niger genome, $\mathrm{CbhA}$ and $\mathrm{CbhB}$ (the products of TID_53159 and TID_51773), are expressed at 156 and 116 RPKM respectively, and together represent 9.9\% of CAZy gene expression. The non-reducing end processive cellobiohydrolases of the GH6 family are also expressed highly due to expression of TID_54490 at 145 RPKM and TID_133986 at 55 RPKM.

Expression of two genes encoding GH12 family enzymes, TID_211053, encoding the endoglucanase EglA, and TID_52011 encoding an enzyme with strong similarity to xyloglucan-specific endo-beta-1,4-glucanase from Aspergillus aculeatus [18,19], at 116 and 49 RPKM respectively account for $6.1 \%$ of CAZy expression.

In addition to the glycoside hydrolase families, the AA9 (formerly GH61 [20]) family of lytic polysaccharide monooxygenases, is also highly expressed and accounts for $8.9 \%$ of CAZy expression. This is almost completely due to the expression of TID_211595 at 247 RPKM. A $5.6 \%$ contribution is also made by the CE1 family of carbohydrate esterases due to high levels of transcription of a single gene, the acetyl xylan esterase, axeA (TID_211544) at 161 RPKM.

This transcript distribution broadly reflects the enzymes required for the saccharification of lignocellulose. The key enzymes involved in the bulk degradation of the cellulose and xylan backbones, i.e. endoglucanases and cellobiohydrolases in the former case and xylanases in the latter, make up the greatest proportion of CAZy expression. Expressed at a lower, but still substantial level, are accessory proteins such as the AA9 family lytic polysaccharide monooxygenases, that are thought to improve the accessibility to the recalcitrant polymers and play a role in depolymerisation of cellulose through oxidative cleavage [21,22]. CE1 esterases, which cleave the acetyl group linkages of xylans [23] are also expressed at a lower, but still sizable level. Notably, there is relatively little expression of the $\beta$-glucosidases and xylosidases when $A$. niger is exposed to willow.

\section{A cross-substrate comparison using transcriptomics}

In an earlier study [5] we delineated the transcriptional profile of $A$. niger under conditions identical to those used here, with the exception that wheat straw was provided as the only lignocellulosic substrate. The composition
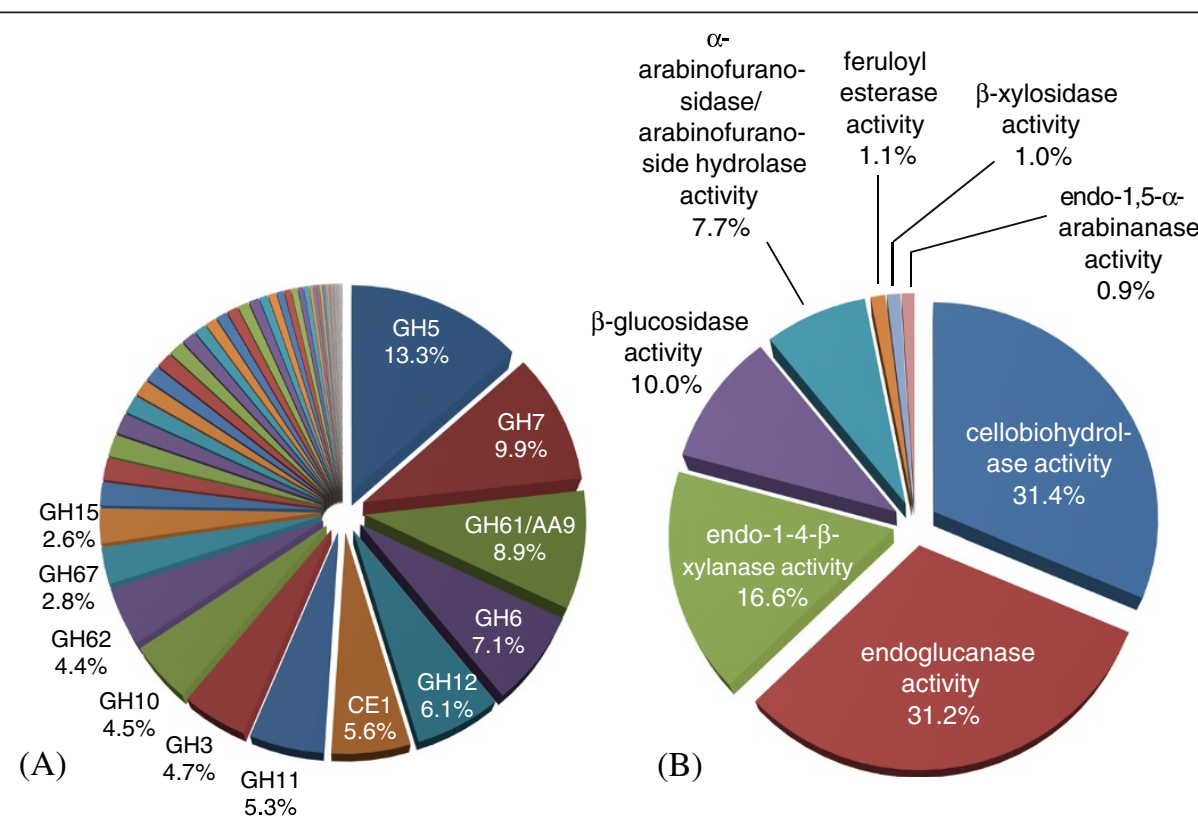

Figure 1 Percentage of transcripts belonging to (A) CAZy families and (B) particular enzyme activities. Expression levels were measured following $24 \mathrm{~h}$ of culturing A. niger in media containing ball-milled willow as the only carbon source. CAZy families representing more than $2 \%$ of total CAZy expression are indicated. The percentage values are the RPKM values for (A) particular CAZy families expressed as a proportion of the total RPKM value of all the families in the GH, CE, PL and AA classes or (B) particular enzyme activities expressed as a proportion of the total RPKM value of all the activities analysed. Classifications for CAZy are according to CAZy.org. Genes were assigned to particular enzyme activities as described in the Methods section and Additional file 7. 
Table 1 Expression of key CAZy-encoding genes that are induced on the willow substrate

\begin{tabular}{|c|c|c|c|c|c|c|}
\hline Gene ID & & Annotation $^{a}$ & CAZy family & & RPKM & \\
\hline ATCC 1015 & CBS513.88 & & & Glucose $48 \mathrm{~h}$ & Willow $^{b} 24 \mathrm{~h}$ & Willow $24 \mathrm{~h}+$ Glucose $5 \mathrm{~h}$ \\
\hline TID_211595 & An12g04610 & Lytic polysaccharide monooxygenase & AA9 & 0.6 & 246.9 & 1.2 \\
\hline TID_209376 & An07g08950 & eglB - Heat- and alkaline-stable endoglucanase & $\mathrm{GH} 5$ & 0.5 & 210.1 & 0.7 \\
\hline TID_211544 & An12g05010 & axeA - Acetyl xylan esterase & CE1 & 0.6 & 161.5 & 0.3 \\
\hline TID_53159 & An07g09330 & cbhA - Putative cellobiohydrolase & $\mathrm{GH} 7$ & 1.0 & 155.7 & 1.2 \\
\hline TID_54490 & An12g02220 & Putative cellulose 1,4-beta-cellobiosidase & CBM1, GH6 & 0.3 & 145.2 & 0.4 \\
\hline TID_205580 & An01g11670 & Endoglucanase A & GH5, CBM1 & 0.2 & 120.6 & 1.6 \\
\hline TID_211053 & An14g02760 & eglA - Putative secreted endoglucanase A & $\mathrm{GH} 12$ & 0.4 & 116.3 & 1.4 \\
\hline TID_51773 & An01g11660 & $c b h B$ - Putative cellobiohydrolase B & $\mathrm{GH} 7, \mathrm{CBM} 1$ & 0.3 & 115.9 & 10.8 \\
\hline TID_133986 & An08g01760 & Putative cellulase; exocellobiohydrolase & $\mathrm{GH} 6$ & 0.2 & 54.9 & 0.5 \\
\hline TID_52011 & An01g03340 & Xyloglucan-specific endo-beta-1,4-glucanase & $\mathrm{GH} 12$ & 0.5 & 49.3 & 0.7 \\
\hline
\end{tabular}

${ }^{a}$ The annotations here are for the A. niger CBS513.88 strain from the AspGD database [44] with the exception that the erroneous endoglucanase annotation for the AA9 family member was corrected.

${ }^{\mathrm{b}}$ All of the genes listed here have significantly increased expression on the willow substrate compared to the glucose $48 \mathrm{~h}$ control ( $p<0.05$, DESeq).

of the wheat straw (as \% of total solids and using the same compositional analysis methods as used for willow) was $37.4 \%( \pm 2.96)$ glucose, $16.8 \%$ xylose $( \pm 2.48)$ and $2.7 \%$ arabinose $( \pm 0.29)$ and the lignin content was $21.6 \%( \pm 0.73)$ (the values in parentheses are standard deviations). Re-calculation of the expression data using the updated genome model and method outlined in this manuscript, allows the direct comparison of the two datasets. A timedependent transcriptome profile on the two different substrates was not feasible but we accept that the transcript profiles may change with time differently on wheat straw or willow. Therefore, we interpret the comparative data cautiously and focus on the major differences for discussion.

Following 24 hours exposure to each substrate, the total CAZy expression induced by willow contributes $15 \%$ of total gene expression, while the equivalent for wheat straw is $21 \%$. Therefore, the CAZy portion of the transcriptome is approximately one third greater in response to wheat straw than willow at this specific time point. Figure $2 \mathrm{com}-$ pares the relative contribution to total gene expression under each condition per CAZy family (for those families in which a total of at least 100 RPKM was achieved on either substrate) and also per selected enzyme activities that the genes encode. There are similarities in the general expression pattern observed, with GH6, 7, 11, 12, CE1 and AA9 being amongst the most highly expressed families on either substrate. For almost all families, relative expression is greater in response to wheat straw than willow, as might be expected when the total expression of CAZy genes overall is one third greater on wheat straw. However, the size of the increase in expression of the CAZy families is not uniform, implying that the difference between the two responses is not simply correlated with the total CAZy expression but instead due to differences in the levels of induction of genes in the CAZy families. In the CE1 family, for example, a single acetylxylan esterase gene, axeA, is highly expressed following exposure to willow (161 RPKM). The gene axeA is also highly expressed following exposure to straw (562 RPKM) with no statistically significant difference in expression compared to willow (DESeq, $\mathrm{P}=0.89$ ). However a second CE1 family member, TID_43785 which is the ortholog of the feruloyl esterase faeC from Aspergillus nidulans [24], is expressed poorly on willow (3 RPKM) but is highly induced (325 RPKM) on wheat straw with a significant 53-fold (DESeq, $p<0.01$ ) increase in expression on straw compared to willow (Table 2 and Additional file 1).

The two most striking differences seen in the pattern of expression of genes encoding entire CAZy enzyme families are in GH62 and GH5. GH62 family members are arabinofuranosidases, a single example of which is encoded within the $A$. niger genome, the 1,4- $\beta$-D-arabinoxylan arabinofuranohydrolase, $a x h A$ (TID_55136) [25], which is expressed at 116 RPKM on willow. The GH62 family is the tenth most expressed family on willow whereas in contrast it is the third most expressed family on straw. This difference in the ranking order of the GH62 family is due to a 3.4 fold increase in expression of axhA (900 RPKM) on straw compared to willow. This trend in expression with the GH62 family member $\operatorname{axh} A$ has been confirmed by qRT-PCR (Additional file 2).

The GH5 family is notable amongst the most highly expressed families for being the only one in which greater expression is seen in response to willow. Whilst the two predominant endoglucanases expressed on willow, TID_20 5580 and TID_209376 (eglC), remain the two most highly expressed members of the family on wheat straw, levels are $\sim 3$-fold reduced for each as calculated using DESeq1.9.

The overall responses to these two different substrates, represented by the hardwood and straw feedstocks, retain a core set of highly induced genes that encode enzymes required for the degradation of any lignocellulosic substrate. Regulatory differences at the level of individual 

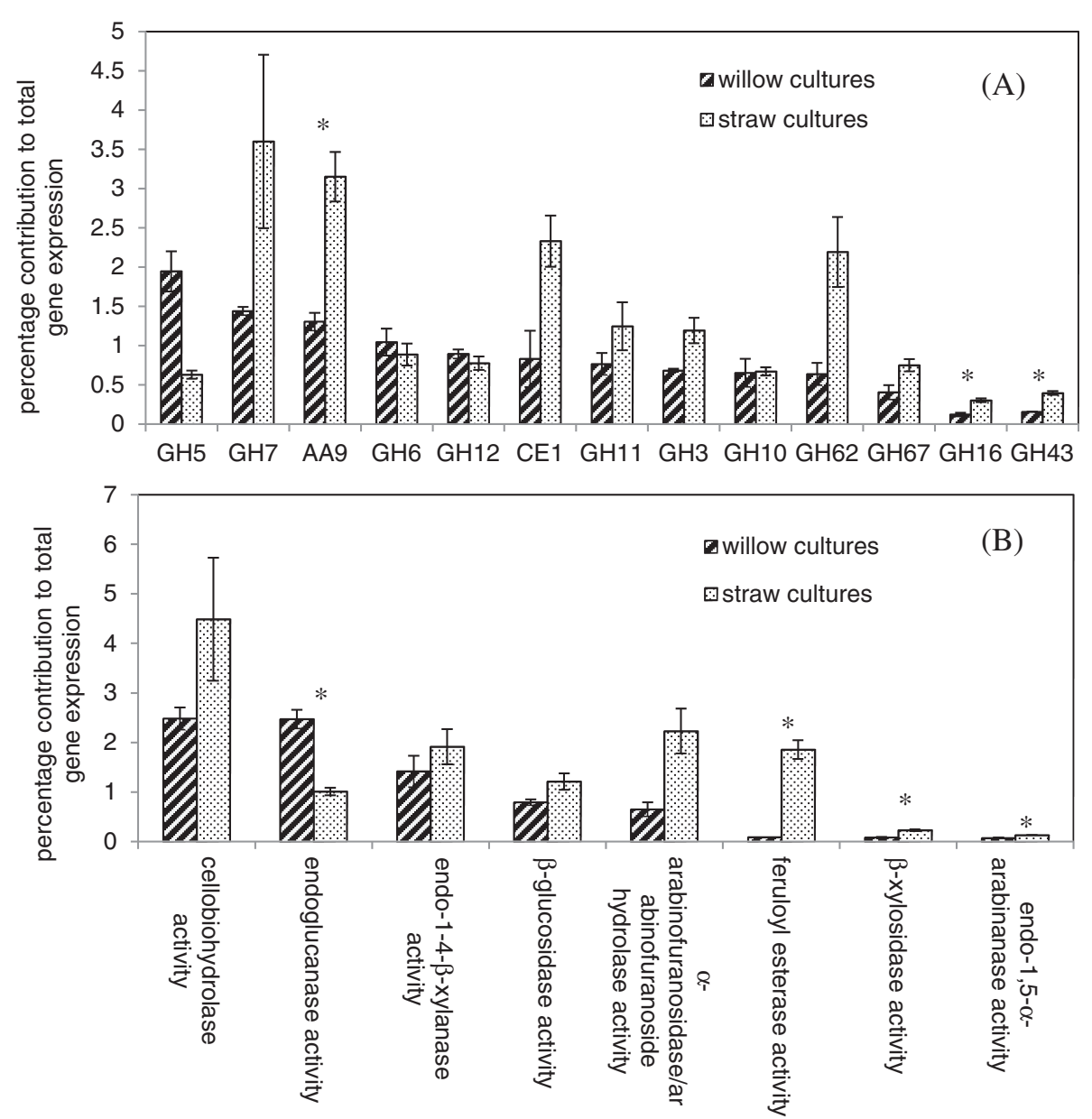

Figure 2 Expression per (A) CAZy family and (B) selected enzyme activities as a percentage of total gene expression. For (A), only those families with total RPKM values of 100 or more upon at least one of the substrates are shown. Gene expression was measured following $24 \mathrm{~h}$ culturing of A. niger in the presence of willow or wheat straw as the only carbon source. The families and activities are presented in order of decreasing expression from the willow cultures. The error bars represent standard error. Genes were assigned to particular enzyme activities as described in Methods section and Additional file $7 . A^{* *}$ symbol is used to indicate whether the differences between willow and straw cultures were statistically significant (unequal variances $t$-test, $p<0.05$ ).

Table 2 Expression of genes that are relevant to the straw and willow substrate comparison

\begin{tabular}{|c|c|c|c|c|c|c|c|}
\hline \multirow{2}{*}{$\begin{array}{l}\text { Gene ID } \\
\text { ATCC } 1015\end{array}$} & \multirow[t]{2}{*}{ Annotation $^{a}$} & \multicolumn{4}{|l|}{ RPKM } & \multirow{2}{*}{$\begin{array}{l}\text { Fold change } \\
\text { straw/willow }\end{array}$} & \multirow{2}{*}{$\begin{array}{l}p \text {-value } \\
\text { straw/willon }\end{array}$} \\
\hline & & $\begin{array}{l}\text { Glucose } \\
48 \mathrm{~h}\end{array}$ & $\begin{array}{l}\text { Straw } \\
24 \mathrm{~h}\end{array}$ & $\begin{array}{l}\text { Glucose } \\
48 \mathrm{~h}\end{array}$ & $\begin{array}{l}\text { Willow } \\
24 \mathrm{~h}\end{array}$ & & \\
\hline TID_43785 & Feruloyl esterase & 0.4 & 325.9 & 0.0 & 3.1 & 52.6 & $<0.01$ \\
\hline TID_182100 & Has domain(s) with predicted hydrolase activity & 0.1 & 16.8 & 0.0 & 0.3 & 28.4 & $<0.01$ \\
\hline TID_51662 & faeA - Feruloyl esterase & 0.4 & 396.3 & 0.0 & 13.0 & 13.9 & $<0.01$ \\
\hline TID_47677 & Putative xylan beta-xylosidase & 0.2 & 76.0 & 0.1 & 9.4 & 3.7 & $<0.01$ \\
\hline TID_55136 & axhA, 1,4-beta-D-arabinoxylan arabinofuranohydrolase & 1.7 & 904.6 & 0.9 & 116.3 & 3.4 & 0.15 \\
\hline TID_211544 & axeA, Acetyl xylan esterase & 0.7 & 562.4 & 0.6 & 161.5 & 1.7 & 0.83 \\
\hline TID_51478 & faeB - Feruloyl esterase & 0.3 & 1.9 & 0.5 & 0.5 & 1.6 & 0.64 \\
\hline TID_205580 & Endoglucanase A & 0.1 & 73.7 & 0.2 & 120.6 & 0.3 & $<0.05$ \\
\hline TID_209376 & Heat- and alkaline-stable endoglucanase & 0.1 & 113.6 & 0.5 & 210.1 & 0.3 & $<0.01$ \\
\hline
\end{tabular}

${ }^{\mathrm{a}}$ The annotations here are for the A. niger CBS513.88 strain from the AspGD database [44].

${ }^{\mathrm{b}}$ The fold changes were calculated by the DESeq statistical analysis package using the normalised read counts. 
genes could have led to the substrate-specific variations in gene expression, which fine-tuned the response of the cells for the degradation of the particular substrate. These variations in gene expression are possibly due to differences in the inducing signals that are generated from the substrates, probably through the generation of small inducing molecules (e.g. sugars and sugar oligomers) from the respective feedstocks. Wheat (a graminaceous (grass) monocot) and willow (a woody dicot) lineages are separated by $\sim 400$ million years of evolution and in that time have evolved different plant cell wall properties.

At the molecular level one of the notable differences between the hemicelluloses of grasses and dicots (reviewed in [6]) is the increased decoration of glucuronoxylan in grasses with arabinose to form glucuronoarabinoxylan. The increased levels of arabinoxylans within grasses may explain the particularly increased expression level seen for the GH62 family on wheat straw as compared to willow. The enzymes within this family are arabinofuranosidases that act to cleave arabinofuranose side chains from the xylan backbone of arabinoxylans [25]. GH43 also includes arabinofuranosidases, many of which display both $\alpha$-Larabinosidase and $\beta$-D-xylosidase activity. Although the overall expression level of this family in these experiments was relatively low on both substrates, there was significantly increased expression on wheat straw compared to willow of two genes, TID_182100 and TID_47677, which were both significantly more highly expressed (28-fold and 4-fold increased respectively, analysed using DESeq1.9, $p<0.001$ ). Arabinose-responsive transcriptional regulation of CAZy enzymes through the AraR regulatory pathway has been described previously in A. niger [26,27].

In addition to hemicellulose composition, the crosslinking between cell wall components also differs between wheat and willow; in grasses such as wheat, ferulic acid linkages connect lignin and hemicelluloses but are largely absent from dicots such as willow [28,29]. There are three genes encoding enzymes with potential ferulic acid esterase activity within the $A$. niger genome faeA, faeB and TID_43785. The gene faeA (TID_51662) has been demonstrated by de Vries and colleagues [30] to encode a ferulate esterase, although it is not officially classified as a carbohydrate esterase by CAZy. After exposure to wheat straw [5], faeA was one of the most highly expressed genes and the expression level as calculated for this study is 396 RPKM. In comparison, the expression of faeA on willow is 13.9-fold lower than the expression on straw. The expression levels of faeA were demonstrated to be regulated by both xylose/xylan and ferulic acid specific systems, with induction stimulated by xylose alone but optimal induction occurring in the presence of ferulic acid in addition to xylose [31]. FaeB (encoded by TID_51478), which is not expressed over 2 RPKM on either substrate has significantly decreased activity towards wheat straw arabinoxylan compared to FaeA [32]. As discussed previously, the putative feruloyl esterase encoded by TID_43785 is one of the most highly differentially expressed genes between the two substrates. The increased expression on wheat straw could indicate that it shares a ferulate-dependent induction system with faeA. The same trend was observed for TID_43785 and faeA using qRT-PCR with a repeat experiment replicating the conditions used for RNA-seq (Additional file 2). These transcriptional observations support the hypothesis that the response of $A$. niger to lignocellulose is fine-tuned by, and linked to, the substrate composition.

\section{Comparison of culture supernatant activity using azurine dyed substrates}

The RNA-seq data suggested transcriptional specificity in the response of $A$. niger to each substrate. To investigate this biochemically, supernatants harvested from $A$. niger cultures incubated with either substrate for $24 \mathrm{~h}$ (the same conditions used for RNA-seq) were assayed for activity towards two azurine-linked substrates: cellulose - a major component of both the wheat straw and willow substrates and arabinoxylan - a hemicellulose found in much greater abundance in wheat straw than willow. Activities in the culture supernatants were assayed using a predetermined volume of the supernatants that gave a linear response between time and azurine dye release. The activity towards arabinoxylan was 10 -fold greater in the straw-induced cocktail compared to the willowinduced cocktail (Table 3). To demonstrate that this higher level of activity towards arabinoxylan could not just be explained by higher total amounts of lignocellulosic active enzymes in the straw cocktail, the activity towards arabinoxylan was expressed as a ratio of the activity towards HE-cellulose. This ratio showed that there was still a greater level of arabinoxylan activity in the straw-induced cocktail because the ratio of the activities was 4-fold greater in the straw-induced cocktail compared to the willow-induced cocktail (Table 3). The greater activity towards arabinoxylan in the wheat straw-induced cocktail has support from the RNA-seq data where the GH62 family gene axhA encoding arabinofuranosidase activity has higher expression in $A$. niger wheat strawinduced cultures compared to the willow-induced cultures. For further investigation of enzyme activities, the supernatants were concentrated so as to allow estimation of the amount of protein and they were then used to saccharify either wheat straw or willow.

\section{Wheat straw induces a greater and different secretory response than willow}

The protein concentration estimated within the concentrated supernatant from wheat straw cultures was approximately twice that from equivalent willow cultures. 
Table 3 Activity towards AZCL HE-cellulose and AZCL arabinoxylan from culture supernatants (S/Ns)

\begin{tabular}{llll}
\hline & HE-cellulose $^{\mathrm{a}}$ & AZCL-arabinoxylan $^{\mathrm{a}}$ & ratio AZCL-arabinoxylan/HE-cellulose \\
\hline $\mathrm{S} / \mathrm{N}$ from A. niger cultured with straw & $0.031(0.0015)^{\mathrm{b}}$ & $1.046(0.0228)^{\mathrm{b}}$ & $\mathbf{3 4 . 0 5}$ \\
$\mathrm{S} / \mathrm{N}$ from A. niger cultured with willow & $0.010(0.0002)^{\mathrm{b}}$ & $0.082(0.0002)^{\mathrm{b}}$ & $\mathbf{8 . 1 7}$ \\
\hline
\end{tabular}

activity is expressed as absorbance units $/ \mu$ l of culture $\mathrm{S} / \mathrm{N}$.

${ }^{b}$ values in parentheses are standard errors.

SDS-PAGE of the two sets of supernatants demonstrated highly reproducible protein mixtures across replicate samples. Whilst some major bands were conserved, clear differences were observed in the banding patterns between the two sets of conditions reflecting the general pattern seen in the transcriptomic data (Additional file 3).

\section{Comparison of culture supernatant activities using para-nitrophenyl linked substrates}

Four para-nitrophenyl linked substrates were used to measure specific enzyme activities in the supernatants from the $A$. niger cultures with straw or willow (Figure 3 ). Slightly higher specific $\beta$-glucosidase (1.28 fold) and $\beta$ xylosidase (1.17 fold) activities were measured in the straw culture supernatants compared to the willow culture supernatants. The cellobiohydrolase specific activity was also higher ( $\sim 3.5$ fold) in the straw culture supernatants. In contrast, the specific $\alpha$-arabinofuranosidase/ arabinofuranoside hydrolase activity was $\sim 2.5$ fold lower in the straw culture supernatants compared to the willow culture supernatants. When these specific activities were compared with the RNAseq data from Figure 2, there were similarities in the trends. There was a significantly higher

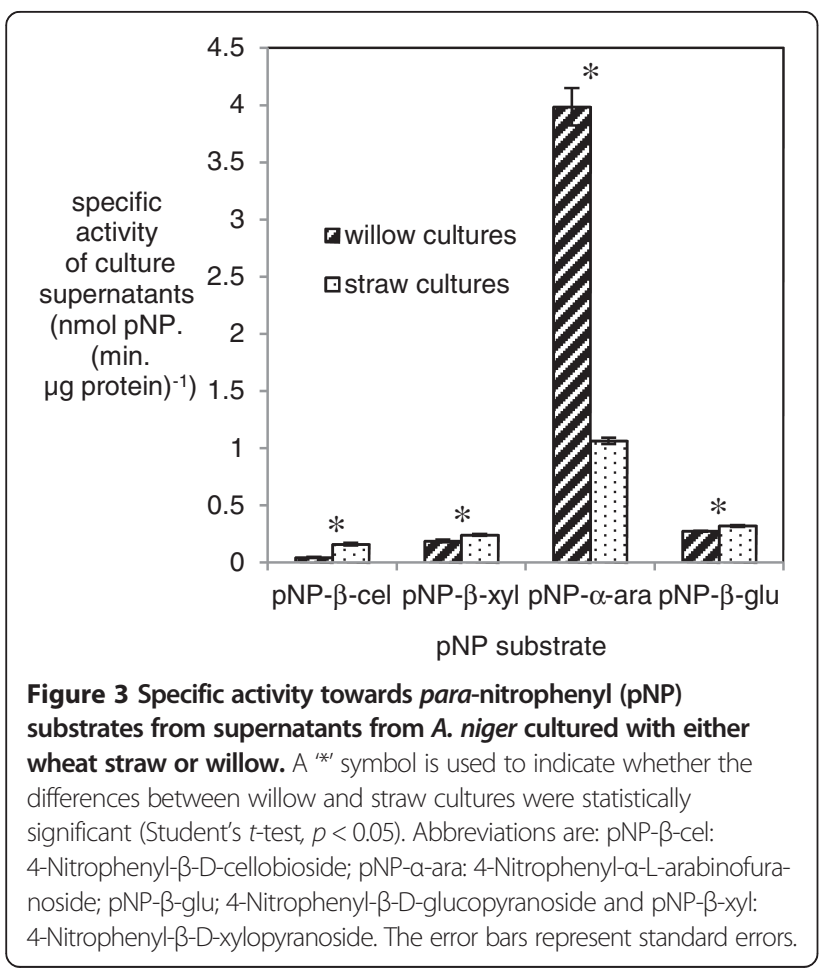

proportion of expression of genes encoding $\beta$-xylosidase activity in the straw cultures. Expression of genes encoding for cellobiohydrolase activity or $\beta$-glucosidase activity was not significantly different in the straw cultures compared to the willow cultures and neither was there a significant difference in the expression of genes encoding for $\alpha$-arabinofuranosidase/arabinofuranoside hydrolase activity between the two cultures although that comparison is complicated by the fact that the majority of the gene expression was from $a x h A$ and AxhA is unable to hydrolyse the $\mathrm{pNP}-\alpha$-arabinofuranoside.

\section{Comparison of culture supernatant activities using saccharification assays}

Over a 48 h saccharification time course using varying concentrations of protein from supernatants of straw or willow cultures, the release of reducing end group equivalents from the straw or willow substrates was periodically assessed using the DNS assay [33] and free glucose levels measured using the GODPOD assay. After $24 \mathrm{~h}$ the levels of free sugars measured were over $80 \%$ of the total measured after $48 \mathrm{~h}$, and therefore this incubation time was chosen as the standard for all further assays (Additional file 4). Over a $24 \mathrm{~h}$ period concentrated samples of supernatant from $A$. niger exposed to wheat straw, containing $55 \mu \mathrm{g}$ of secreted proteins, released on average $0.096 \mathrm{mg}$ of reducing end group equivalents per mg of wheat straw substrate (as measured by the DNS assay) whilst only $0.042 \mathrm{mg}$ of reducing end group equivalents per $\mathrm{mg}$ of willow was released over the same time period (Figure 4). Similarly the supernatant taken from $A$. niger exposed to willow (which contained an equivalent amount of protein to the supernatant assayed from $A$. niger exposed to straw) released $0.042 \mathrm{mg}$ of reducing end group equivalents per mg of willow substrate, but only 0.030 mg was released per mg of wheat straw. These results show that the wheat straw-induced enzyme cocktail had over double the activity towards wheat straw than it does towards willow, and the willow-induced enzyme cocktail shows a $40 \%$ greater activity towards willow compared to wheat straw. Both of these differences are statistically significant ( $p<0.05$, Student's $t$-test). Use of the GODPOD assay for free glucose monomers present within the digest products showed a similar pattern to the DNS assay (Figure 4) at approximately one third of the levels seen in the DNS assay. These proportions may indicate that the primary target of degradative activity in 


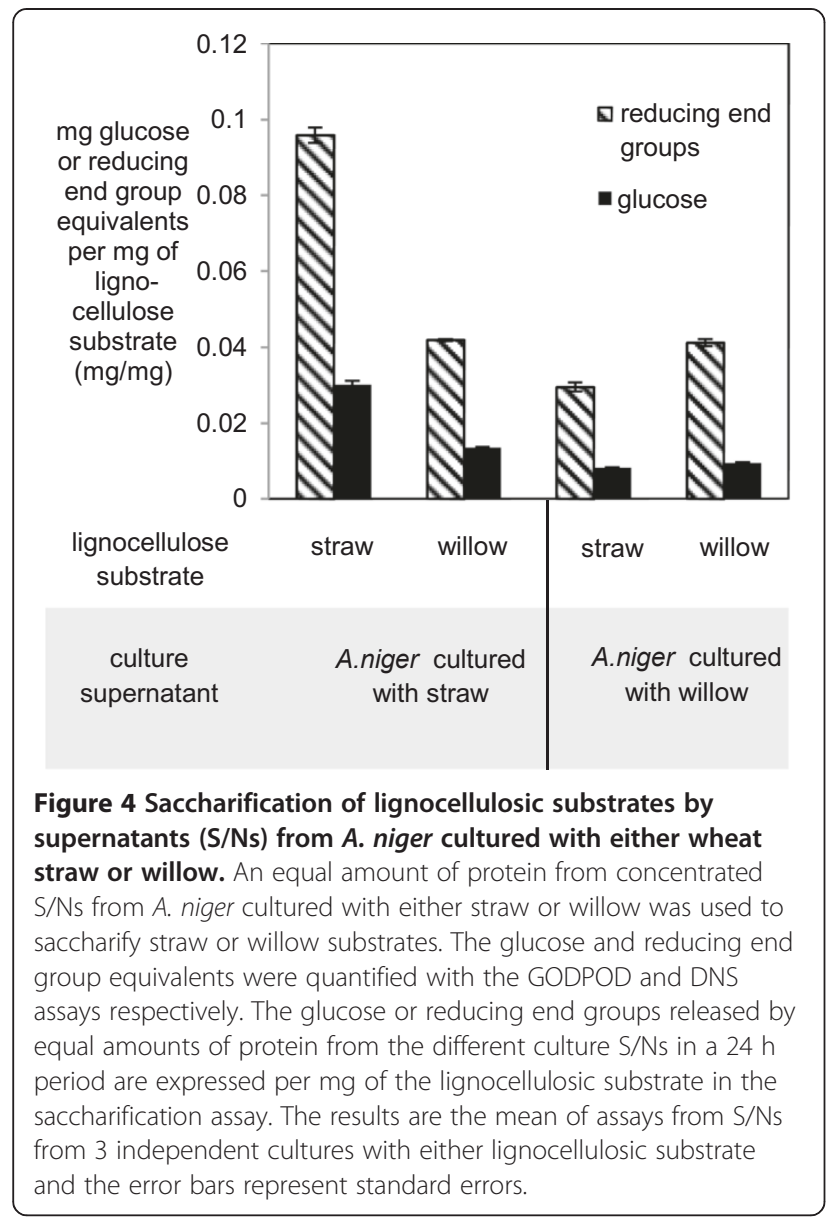

the assays was hemicellulose rather than the glucose-rich cellulosic fraction or that a significant number of oligomers are being released. These assay values are comparable to those in other studies with similar methodologies [34].

\section{The lignocellulosic substrate used can have a specific effect on induction}

The data presented in this study show that the lignocellulosic substrate used to induce the expression of genes encoding degradative enzymes can have a specific effect on the combination of enzymes produced. Wheat straw and willow induced a central core set of shared genes that are likely to be induced by a wide variety of lignocellulosic substrates, but also showed significant differences in the induction of genes encoding both particular GH families and individual genes. This is likely due to the integration of several different regulatory pathways that respond to either different inducing molecules present within the substrates, or else the differences in concentration or proportions of such inducing molecules. Such a system may have evolved to give $A$. niger the ability to adapt its degradative response to match the available substrate within its natural environment. Of the two ball-milled substrates compared in this study, wheat straw led to a larger scale response at the transcriptomic level that was matched by an increased concentration of proteins within the culture supernatant.

With regard to the enzyme activities, the strawinduced enzyme cocktail out-performed the willowinduced cocktail. As well as the wheat straw-induced cocktail saccharifying straw to a greater extent than the willow-induced cocktail, the straw-induced cocktail saccharified willow to the same extent as the willowinduced cocktail. Both cocktails released almost identical amounts of reducing end group equivalents from willow in the DNS assay (Figure 4). The out-performing by the straw-induced cocktail of the willow-induced cocktail may reflect the intrinsically greater recalcitrance of a woody substrate such as willow over a gramineous substrate such as straw rather than differences in specificities of the cocktails. It is possible that any specificity in the willow-induced cocktail towards willow is masked by this greater recalcitrance of the willow substrate.

\section{Effect of sugars initially present and released over time in the lignocellulose media}

The insoluble polymers and soluble inducing molecules related to these polymers may not be the only factors leading to differences in gene expression. There may be a role for the higher amount of free glucose present initially and released in early time points from the willow media compared to the straw media by $A$. niger. This glucose could delay the onset of induction of CAZy genes longer than in the straw media due to CreA repression which would only be alleviated when the free glucose became exhausted. Sugar analysis showed that there was a greater amount of free glucose present initially and released from the substrate by $A$. niger over time in the willow media compared to the straw media (Additional file 5) [5]. Differences in the timing of transcriptional induction and enzyme secretion, as well as with fungal growth rate, could be investigated in future work with straw and willow substrates. This free glucose and other sugars, while a complicating factor in comparing the response to different substrates, are unavoidable because performing some form of extraction or washing of the lignocellulose substrate will likely remove other small soluble molecules relevant to induction. Even so, the level of free glucose in lignocellulosic substrates initially and released over time are variables to consider when comparing the fungal response to different lignocellulosic substrates. In the study reported here, the levels of free glucose at the outset were very low compared to the amount of fungal biomass added and would not support a significant increase in fungal biomass. 


\section{Non-CAZy responses to lignocellulose}

In a previous wheat straw study, we identified 28 genes not categorised as members of any CAZy category that had significantly higher transcript levels in response to wheat straw, using a cut-off of a minimum 20 -fold induction relative to expression in the glucose media [5]. We divided those genes into four defined categories, encoding: esterases and lipases, surface-interacting proteins, carbon and nitrogen metabolising enzymes, and transporters. The expression of these 28 genes was examined in $A$. niger after exposure to willow for $24 \mathrm{~h}$ (Table 4 and Additional file 1). Of the 7 genes included in the lipase/esterase category, four genes were induced significantly by at least 50-fold following the switch from glucose to willow media and were expressed at an RPKM of $>10$. Some of the encoded proteins have been biochemically characterised as possessing lignocellulosic degrading activity (e.g. the ferulic acid esterase, FaeA [30]). For two uncharacterised genes TID_173684 and TID_54865, our data support the notion that they could function in the degradation of lignocelluloses and are induced by a factor common to wheat straw and willow.

The surface-interacting proteins category consisted of 4 genes with two of these genes encoding hydrophobins, another gene (TID_188224) which is a homolog of a hydrophobic surface binding protein $h s b A$ from $A$. oryzae [35] and one gene (TID_54125) which encoded a protein with homology to a transmembrane protein Pth11p of Magnoporthe grisea [36]. All of these four proteins have homology to proteins involved in the sensing of, or physical association with, hydrophobic surfaces and promotion of substrate degradation [35,37]. Transcripts from three of these genes had higher expression levels in the presence of willow as compared to glucose media, with the exception being the hydrophobin-encoding TID_128530. However, the only member of this category expressed on willow at an RPKM of $>10$ was TID_188224 at 721 RPKM, further supporting the hypothesis that this protein may play a role in fungal response to lignocellulose. Interestingly, the expression in response to willow was 32 -fold greater than that to straw (DESeq, $\mathrm{p}<0.01$ ).

Of the carbon and nitrogen metabolising category, only 2 of the 5 genes had transcript levels raised by $>20$-fold by wheat straw and willow (TID_51997 and TID_52460). This, in a similar manner to the CAZy response, could reflect differences in composition of the substrates and the small metabolites released during their degradation. All genes within the transporters category had transcript levels raised $>20$-fold on willow. In our previous study with straw, five other genes were induced on straw but could not be easily categorised so we categorised as 'Others'. One of these genes TID_120161, was induced on willow with expression > 10 RPKM. The gene TID_120161 encodes a protein with homology to mitochondrial ceramidase.
The non-CAZy genes in Table 4 that are induced on willow but are not yet characterised are good candidates for future study. Overall the comparison between substrate induction profiles shown is similar for both CAZy family genes and non-CAZy related genes, insofar as the broad picture is of a similar response to willow and wheat straw by $A$. niger with differences at the level of individual genes.

\section{Conclusions}

In the context of enzyme production for use in second generation biofuel processes, the data clearly demonstrate two key points. Firstly, the inducing substrate used for the production of enzymes has marked effects upon the enzyme cocktail achieved highlighting the limitations of the use of simple inducing substrates for the generation of complex enzyme mixtures. Secondly, the relationship between the inducing substrate and the activity of the cocktail secreted from this induction is not straightforward. For example, the wheat straw-induced cocktail was more effective at saccharifying straw than the willow-induced cocktail but the willow-induced cocktail was not more effective as saccharifying willow than the wheat straw-induced cocktail. While the cost effectiveness of using simple inducing substrates together with de-repressed fungal strains cultured on glucosecontaining media has clear attractions, fungi have an enzymatic capability that can currently best be realised with induction by complex substrates. As more detailed knowledge of the complexities of how fungi efficiently saccharify lignocelluloses emerges, it will become possible to incorporate that knowledge into production procedures for more efficient and complex enzymatic cocktails. Also, the effectiveness of wheat straw as a general inducing substrate compared with other potential biofuel feedstocks could also be explored. Wheat straw induces a robust response, with good activity towards a variety of cellulose and isolated hemi-cellulosic substrates as well as towards willow and wheat straw.

\section{Methods}

\section{Substrate preparation}

Short rotation coppice willow (Salix sp.) Tora variety stems were knife-milled using a Fritsch pulverisette 19 knife-mill (Fritsch, Germany) by first passing the stems through a $2 \mathrm{~mm}$ screen and then a $0.5 \mathrm{~mm}$ screen for size reduction prior to ball-milling. $5 \mathrm{~g}$ of knife-milled willow was ball-milled in $80 \mathrm{~mL}$ stainless steel grinding bowls with $2510-\mathrm{mm}$-diameter steel balls in a Planetary Mill (Pulverisette 5 classic line, Fritsch, Germany), at 400 rpm for a grinding time of $20 \mathrm{~min}$, resulting in an average particle size of $<75 \mu \mathrm{m}$. The wheat straw substrate preparation was described previously [5]. 
Table 4 Expression of genes relevant to the non-CAZy response of $A$. niger to willow

\begin{tabular}{|c|c|c|c|c|c|c|c|}
\hline \multirow{2}{*}{$\begin{array}{l}\text { Gene ID } \\
\text { ATCC } 1015\end{array}$} & \multirow{2}{*}{ CBS513.88 } & \multirow[b]{2}{*}{$\begin{array}{l}\text { Gene name (if any) and } \\
\text { annotation }^{\mathrm{a}} \text { (abbreviated) }\end{array}$} & \multicolumn{3}{|l|}{ RPKM } & \multirow{2}{*}{$\begin{array}{l}\text { Fold change }{ }^{b} \text { Willow } \\
24 \text { h/glucose } 48 \text { h }\end{array}$} & \multirow{2}{*}{$\begin{array}{l}p \text {-value Willow } \\
24 \text { h/glucose } 48\end{array}$} \\
\hline & & & $\begin{array}{l}\text { Glucose } \\
48 \mathrm{~h}\end{array}$ & $\begin{array}{l}\text { Willow } \\
24 \mathrm{~h}\end{array}$ & $\begin{array}{l}\text { Willow } 24 \mathrm{~h}+ \\
\text { Glucose } 5 \mathrm{~h}\end{array}$ & & \\
\hline \multicolumn{8}{|c|}{ Esterases \& Lipases } \\
\hline TID_173684 & An02g09690 & $\begin{array}{l}\text { Ortholog(s) have role in fatty } \\
\text { acid catabolic process }\end{array}$ & 0.50 & 21.96 & 0.22 & 98.05 & $<0.01$ \\
\hline TID_51662 & An09g00120 & faeA, Feruloyl esterase & 0.00 & 13.01 & 0.06 & N/A & $<0.01$ \\
\hline TID_50877 & An13g01880 & Triacylglycerol lipase & 0.00 & 0.98 & 0.00 & $\mathrm{~N} / \mathrm{A}$ & $<0.01$ \\
\hline TID_210730 & An16g01880 & lipanl, Lysophospholipase & 0.36 & 62.07 & 0.72 & 379.56 & $<0.01$ \\
\hline TID_54865 & N/A & N/A & 0.02 & 27.43 & 0.16 & 2713.67 & $<0.01$ \\
\hline This Study & An03g06560 & Triacylglycerol lipase & 0.00 & 0.05 & 0.00 & N/A & 0.65 \\
\hline TID_53620 & An16g03700 & $\begin{array}{l}\text { Has domain(s) with predicted } \\
\text { hydrolase activity }\end{array}$ & 0.05 & 11.07 & 14.25 & 531.54 & $<0.01$ \\
\hline \multicolumn{8}{|c|}{ Surface-interacting Proteins } \\
\hline TID_128530 & An07g03340 & hyp 1, Hydrophobin & 4.21 & 2.30 & 4.92 & 1.09 & 1.00 \\
\hline This Study & An08g09880 & Putative hydrophobin & 1.40 & 6.33 & 5.62 & 9.53 & $<0.01$ \\
\hline TID_188224 & An09g00840 & $\begin{array}{l}\text { Putative cell wall } \\
\text { galactomannoprotein }\end{array}$ & 1.31 & 721.16 & 2.13 & 1075.30 & $<0.01$ \\
\hline TID_54125 & An18g02730 & $\begin{array}{l}\text { Ortholog of A. nidulans FGSC A4: } \\
\text { AN3257 }\end{array}$ & 0.12 & 3.36 & 0.73 & 59.77 & $<0.01$ \\
\hline \multicolumn{8}{|c|}{ Enzymes of Carbon and Nitrogen Metabolism } \\
\hline TID_51997 & An01g03740 & D-xylose reductase & 0.25 & 27.73 & 0.25 & 242.13 & $<0.01$ \\
\hline TID_52460 & An02g13750 & $\begin{array}{l}\text { Ortholog(s) have extracellular } \\
\text { region localization }\end{array}$ & 2.60 & 35.39 & 6.74 & 28.40 & $<0.01$ \\
\hline TID_40496 & An15g02410 & $\begin{array}{l}\text { Has domain(s) with predicted } \\
\text { nucleotide binding activity }\end{array}$ & 3.71 & 2.98 & 4.41 & 1.72 & 0.59 \\
\hline TID_40740 & An15g05990 & $\begin{array}{l}\text { Has domain(s) with predicted } \\
\text { nucleotide binding...activity }\end{array}$ & 0.25 & 0.48 & 0.23 & 3.69 & 0.60 \\
\hline TID_56084 & An11g10890 & Aldose 1-epimerase & 2.37 & 10.48 & 0.50 & 9.75 & $<0.01$ \\
\hline \multicolumn{8}{|l|}{ Transporters } \\
\hline TID_56643 & An12g09270 & Putative lactose permease & 0.12 & 38.20 & 1.72 & 676.84 & $<0.01$ \\
\hline TID_38375 & An08g04040 & transmembrane transporter activity & 0.53 & 7.98 & 0.84 & 32.31 & $<0.01$ \\
\hline TID_55668 & An06g00560 & transmembrane transporter activity & 0.19 & 24.08 & 0.30 & 263.55 & $<0.01$ \\
\hline TID_180069 & An07g02540 & transmembrane transporter activity & 0.10 & 2.05 & 0.75 & 43.05 & $<0.01$ \\
\hline TID_197549 & An02g08230 & transmembrane transporter activity & 0.26 & 18.83 & 0.09 & 146.66 & $<0.01$ \\
\hline TID_54095 & An18g01700 & transmembrane transporter activity & 0.09 & 2.83 & 0.15 & 65.55 & $<0.01$ \\
\hline TID_54838 & An13g03110 & $\begin{array}{l}\text { Has domain(s) with predicted role } \\
\text { in transmembrane transport }\end{array}$ & 0.35 & 5.77 & 0.11 & 34.61 & $<0.01$ \\
\hline \multicolumn{8}{|l|}{ Others } \\
\hline TID_120161 & An18g05500 & $\begin{array}{l}\text { Ortholog(s) have extracellular region } \\
\text { localization }\end{array}$ & 0.64 & 16.86 & 0.14 & 56.34 & $<0.01$ \\
\hline TID_42809 & An18g03380 & Ortholog(s) have lgE binding activity & 0.13 & 4.23 & 1.31 & 69.84 & $<0.01$ \\
\hline TID_180489 & An07g00070 & Protein of unknown function & 2.84 & 1.66 & 2.29 & 1.21 & 1.00 \\
\hline TID_53013 & An11g07040 & $\begin{array}{l}\text { Ortholog of A. niger ATCC } 1015 \text { : } \\
\text { 53013-mRNA }\end{array}$ & 0.07 & 8.61 & 0.10 & 233.95 & $<0.01$ \\
\hline TID_43786 & An12g02560 & N/A & 0.13 & 0.18 & 0.17 & 3.20 & 0.92 \\
\hline
\end{tabular}

The annotations here are for the A. niger CBS513.88 strain from the AspGD database [44].

${ }^{\mathrm{b}}$ The fold changes were calculated by the DESeq statistical analysis package using the normalised read counts. 


\section{Substrate compositional analysis}

The total sugar in processed ball milled biomass was quantified in the hydrosylate after acid hydrolysis [38]. $30 \mathrm{mg}$ of dried ball milled biomass was weighed and subjected to a two stage acid hydrolysis initially with $12 \mathrm{M}$ sulphuric acid for 1 hour at $37^{\circ} \mathrm{C}$ followed by $1 \mathrm{M}$ sulphuric acid for 2 hours at $100^{\circ} \mathrm{C}$. The monosaccharide analysis was performed on fully acid hydrolysed residues and high-performance anion exchange chromatography with pulsed amperometric detection (HPAEC-PAD) (Dionex, UK) using a CarboPac PA20 column with $50 \mathrm{mM} \mathrm{NaOH}$ isocratic system at working flow rate of $0.5 \mathrm{ml} / \mathrm{min}$ at $30^{\circ} \mathrm{C}$. Glucose, xylose, arabinose and galactose were used as standards with mannitol as an internal standard. The acetyl bromide method was performed to quantify lignin in ball milled biomass [39]. The details of the lignin analysis method are the same as described previously [5]. The sugar and lignin analyses were performed using three technical replicates.

\section{Strains and growth conditions}

The $A$. niger strain used was N402 [40] and it was routinely maintained on potato dextrose agar (Oxoid). Cultures were incubated at $28^{\circ} \mathrm{C}$ until they had conidiated (produced asexual spores). Spores were harvested into $0.1 \%(\mathrm{v} / \mathrm{v})$ Tween 20 (Sigma). Liquid batch cultures were inoculated with spores to a final concentration of $10^{6}$ spores $\mathrm{ml}^{-1}$. A. niger was grown in $100 \mathrm{ml}$ of minimal media [all $\mathrm{l}^{-1}$ : $\mathrm{NaNO}_{3}, 6$ g; KCl, 0.52 g; $\mathrm{MgSO}_{4} .7 \mathrm{H}_{2} \mathrm{O}, 0.52 \mathrm{~g} ; \mathrm{KH}_{2} \mathrm{PO}_{4}$, 1.52 g; $\mathrm{Na}_{2} \mathrm{~B}_{4} \mathrm{O}_{7} .10 \mathrm{H}_{2} \mathrm{O}, 0.008 \mathrm{mg} ; \mathrm{CuSO}_{4} .5 \mathrm{H}_{2} \mathrm{O}, 0.16 \mathrm{mg}$; $\mathrm{FePO}_{4} \cdot \mathrm{H}_{2} \mathrm{O}, 0.16 \mathrm{mg} ; \mathrm{MnSO}_{4} .4 \mathrm{H}_{2} \mathrm{O}, 0.16 \mathrm{mg} ; \mathrm{NaMo}$ $\mathrm{O}_{4} \cdot 2 \mathrm{H}_{2} \mathrm{O}, 0.16 \mathrm{mg} ; \mathrm{ZnSO}_{4}, 1.6 \mathrm{mg}$ ] with the appropriate carbon source added to a final concentration of $1 \%(\mathrm{w} / \mathrm{v})$ in $250 \mathrm{ml}$ Erlenmeyer flasks at $28^{\circ} \mathrm{C}$, shaken at $150 \mathrm{rpm}$. The standard time-course consisted of growth from spores for $48 \mathrm{~h}$ in $1 \%(\mathrm{w} / \mathrm{v})$ glucose media, after which mycelia were removed by filtration through Miracloth (Merck), washed thoroughly with media devoid of carbon source, and transferred to fresh media containing autoclaved $1 \%(\mathrm{w} / \mathrm{v})$ ball-milled willow or wheat straw [5] as sole carbon source. Incubation was continued for $24 \mathrm{~h}$. For the RNA-seq study, RNA from two further cultures was extracted where glucose (at $1 \%(\mathrm{w} / \mathrm{v})$ was added to the willow cultures after $24 \mathrm{~h}$ and the incubation continued for a further $5 \mathrm{~h}$.

\section{RNA extraction}

Mycelia from duplicate independent cultures for each condition were frozen and ground under liquid nitrogen using a mortar and pestle, then RNA purified using the Plant/Fungi total RNA Purification Kit (Norgen Biotek, Canada) including the on-column DNase treatment step. The concentration and quality of RNA for each sample was determined by UV spectrometry (Nanodrop ND-1000 spectrophotometer).

\section{qRT-PCR}

SuperScript ${ }^{\text {tux }}$ III Reverse Transcriptase (Invitrogen) was used to synthesise cDNA from total RNA according to manufacturer's instructions, using oligo (dT) as primer. $0.5 \mu \mathrm{g}$ of total RNA was used for each reverse transcription. Quantitative RT-PCR amplifications were carried out using the Applied Biosystems 7500 Fast Real-Time PCR system. The PCR reaction mixture $(10 \mu \mathrm{l})$ contained $1 \mu \mathrm{l}$ of cDNA, specific primer sets (200 nM final concentration), and FAST SYBR-Green Master Mix (Applied Biosystems). PCRs were conducted with an initial denaturation at $95^{\circ} \mathrm{C}$ for $20 \mathrm{~s}$, followed by 40 cycles of denaturation at $95^{\circ} \mathrm{C}$ for $3 \mathrm{~s}$ and annealing and elongation at $60^{\circ} \mathrm{C}$ for $30 \mathrm{~s}$. Three biological replicates (shake flasks) were assayed with duplicate technical repeats of the qRT-PCR reactions. The specificity of primer sets used for qRT-PCR amplification was evaluated by melting curve analysis. The relative standard curve method was used for relative quantification using genomic DNA as the standard. All primers used, and sequences are listed in Additional file 6.

\section{RNA sequencing}

A total of $10 \mu \mathrm{g}$ of total RNA was depleted of ribosomal RNA using the Ribominus Eukaryotic kit (Invitrogen). Transcriptome libraries were prepared and sequenced as described [5] with the following exceptions; the KAPA library quantification kit for Life Technologies SOLiD platform was used to quantify the libraries by qPCR. Emulsion PCR and bead-based enrichment was carried out using the SOLiD EZ bead system. Using a SOLiD 5500xl ABi sequencer, 50bp/35bp paired-end reads were generated in colour space.

\section{Read mapping and quantification}

The Life Technologies LifeScope (v2.5.1) Whole Transcriptome (WT) Pipeline was used to filter, then map the SOLiD reads to the reference genome sequence described before [41] using the mate-pair read WT pipeline. The RNA-Seq data obtained previously [5] of $A$. niger exposed to wheat straw for $24 \mathrm{~h}$, as well as the data from the corresponding glucose cultures, were reanalysed using the same WT pipeline to allow data comparison. Reads from this dataset were mapped using the single fragment WT pipeline. For both data sets, reads were initially filtered against library adaptor and barcode sequences as well as A. niger rRNA 5.8S, 16S, 18S \& $28 \mathrm{~S}$ sequences obtained from Genbank. Reads that passed the filter were then mapped to the reference genome sequence, and to a library of exon junction sequences derived from the genome sequence using 
known exon coordinates. This allowed reads that spanned exon junctions (spliced reads) to be determined. Read counts per gene were determined using the program Htseq-count (http://www-huber.embl.de/users/anders/ HTSeq) using uniquely aligned reads with $\geq$ MAPQ20. For paired read alignments only the forward read (F3) were counted. The count information was then used to calculate normalized gene expression values as RPKM [12]. Read counts were also used as the input for calculating differentially expressed (DE) genes using the $R$ package DESeq (version 1.9) [42]. An adjusted p-value of $\leq 0.05$ was the significance threshold ( $p$-value adjusted for multiple testing with the Benjamini-Hochberg procedure for false discovery rate (FDR)). Where fold changes in gene expression are described in the results from our study, the fold changes are those calculated by DESeq using the normalised count data. The RNA-Seq data obtained previously for $24 \mathrm{~h}$ exposure to wheat straw [5] is available at the Gene Expression Omnibus (GEO) database [43] under accession number GSE33852 and the data obtained in this study for 'willow $24 \mathrm{~h}$ ' and 'willow $24 \mathrm{~h}+$ glucose $5 \mathrm{~h}$ ' along with the corresponding glucose $48 \mathrm{~h}$ control cultures are available under accession number GSE62284. Additional file 1 contains the expression levels for all genes.

\section{Gene annotation datasets used}

The CAZy annotation for A. niger from cazy.org [15,16] was used (last updated July 2013). The annotations for A. niger genes for the CBS513.88 strain were downloaded from the AspGD database [44]. A combination of sources was used to assign genes with particular activities including the enzyme commission (EC) number annotations [10] and cazy.org annotations [11,45]. See Additional file 7 for a summary of which activities were assigned to particular genes based on the sources listed above.

\section{Enzyme assays with AZCL dyed substrates}

The activity of enzymes in the supernatant was measured by degrading the Azurine-Cross-linked (AZCL) polysaccharides HE-cellulose and arabinoxylan (Wheat) (Megazyme, Wicklow, Ireland). $10 \mathrm{mg}( \pm 0.5 \mathrm{mg})$ of the AZCL dyed substrates were incubated in a total volume of $1 \mathrm{ml}$ of 100 $\mathrm{mM}$ sodium acetate buffer $\mathrm{pH} 4.5$ with un-concentrated supernatant. A volume of $10 \mu \mathrm{l}$ of the supernatant was used for the assays with AZCL arabinoxylan and $100 \mu$ for the assays with AZCL HE-cellulose. The reactions were incubated for $30 \mathrm{~min}$ at $50^{\circ} \mathrm{C}$. These conditions gave a linear response between time and dye release with the above volumes. The reactions were stopped with $500 \mu \mathrm{l} 2 \%$ Tris base $(\mathrm{pH} \sim 8)$. After centrifugation, the samples were diluted if needed and the absorbance was measured at 590 $\mathrm{nm}$. The activity was expressed as dye released (as measured by absorbance adjusting for any dilution made to read within the absorbance range of the spectrophotometer) per volume of supernatant assayed in $30 \mathrm{~min}$.

\section{Saccharification assays with secreted $A$. niger proteins}

Six $100 \mathrm{ml}$ shake flask cultures of $A$. niger with either straw or willow substrate were incubated for $24 \mathrm{~h}$ at $28^{\circ} \mathrm{C}$. The supernatants from two of the shake flask $100 \mathrm{ml}$ cultures were combined to form a replicate of secreted proteins for the saccharification experiments. The supernatants were centrifuged to pellet any solids, then filtered through $5 \mu \mathrm{m}$ filters (surfactant-free cellulose acetate (SFCA), Sartorius) before $\sim 120 \mathrm{ml}$ of the supernatant was concentrated to $8 \mathrm{ml}$ ( 15 fold concentration) with Vivaspin columns (5000 MWCO, Sartorius). The concentrated supernatants were flash frozen in liquid nitrogen and stored at $-80^{\circ} \mathrm{C}$. The protein contents of the concentrated supernatants were estimated with the RC DC Protein Assay (Biorad) using BSA as a standard. For the saccharification assay, solutions of $1 \% \mathrm{w} / \mathrm{v}$ of lignocellulose substrates in AMM media were autoclaved at $117^{\circ} \mathrm{C}$ in the same manner as the lignocellulose substrates were prepared for the $A$. niger lignocellulose cultures. Saccharification reactions were performed in $2 \mathrm{ml}$ tubes in a total volume of $1.5 \mathrm{ml}$ with $15 \mathrm{mg}$ of washed autoclaved substrate, equal protein quantities $(55 \mu \mathrm{g})$ of each the concentrated supernatants, $50 \mathrm{mM}$ citrate buffer $\mathrm{pH}$ 4.8 and sodium azide at a $0.02 \% \mathrm{w} / \mathrm{v}$ final concentration. Reactions were incubated for $24 \mathrm{~h}$ at $50^{\circ} \mathrm{C}$ with moderate shaking. At the end of the incubation, the enzymes were inactivated by heating at $100^{\circ} \mathrm{C}$ for $5 \mathrm{~min}$ followed by centrifugation to pellet the solids. The total reducing sugars and other reducing end groups were quantified with the DNS assay [33] using glucose as a standard. Glucose was quantified with the GOPOD assay (Megazyme). Both the DNS assay and the GOPOD assays were performed in a 96-well plate format.

\section{Enzyme assays with pNP substrates}

Concentrated culture filtrates from the same flask cultures used for the saccharification assays were assayed using 4-Nitrophenyl- $\beta$-D-cellobioside (pNP-cel), 4-Nitrophenyl$\alpha$-L-arabinofuranoside (pNP-ara), 4-Nitrophenyl- $\beta$-Dglucopyranoside (pNP- $\beta$-glu) and 4-Nitrophenyl- $\beta$-Dxylopyranoside (pNP-xyl) (all from Sigma). With assay conditions that gave a linear response between time and pNP release, the concentrated culture filtrate was assayed in a total volume of $130 \mu \mathrm{l}$ with $2.5 \mathrm{mM}$ final concentration of the substrate in $50 \mathrm{mM}$ sodium acetate $\mathrm{pH}$ 5.0. The reactions were incubated at $37^{\circ} \mathrm{C}$ for $30 \mathrm{~min}$ with shaking, and then stopped with $130 \mu \mathrm{l}$ of $1 \mathrm{M}$ sodium carbonate before the absorbance was measured at $405 \mathrm{~nm}$ with a plate reader (Biotek). The enzyme activity was expressed in nmoles pNP per minute per ug protein ( $\mathrm{nmol}$ pNP . (min. $\mu$ g protein $\left.)^{-1}\right)$. 


\section{Sugar analysis of willow media before and during incubations}

The methodology for the sugar analysis of the willow media before and during incubation with $A$. niger is as described previously for the incubation with wheat straw media [5].

\section{PAGE gel analysis}

Equal amounts of protein from the concentrated culture supernatants $(\mathrm{S} / \mathrm{N})$ were analysed by SDS-PAGE. The concentrated culture S/Ns were denatured and run on a 4-20\% Tris-glycine PAGE gel (Life Technologies) as described previously [5]. A pre-stained protein ladder (NEB, Cat. \# P7711S) was also run on the gel. The gel was subsequently silver stained [46].

\section{Additional files}

Additional file 1: Full list of RPKM values and $p$-values from the statistical analysis for all genes from $A$. niger for all the conditions described in this study. The subset of CAZy genes is also presented as a separate sheet within the workbook.

Additional file 2: Expression measured by qRT-PCR for TID_43785, faeA and axhA genes. Relative transcript levels for TID_55136 (axhA), TID_43785 (a CE1 family esterase) and TID_51662 (faeA). The expression level in A. niger cultured with willow is expressed relative to the expression level in one of the $A$. niger cultures with straw replicates. The expression is normalised to two reference gene sarA and act. RNA from three replicate $A$. niger cultures with each substrate were assayed here. The error bars represent standard errors.

Additional file 3: SDS-PAGE gel of denatured concentrated supernatants $(\mathrm{S} / \mathrm{Ns})$ from $A$. niger cultured with either wheat straw or willow. The 4-20\% Tris-glycine SDS-PAGE gel was loaded with $0.5 \mu \mathrm{g}$ of denatured protein as measured by the Biorad RC DC assay in lanes 2-7 and silver-stained. Lanes 2-4 contained S/N from A. niger cultured with straw and lanes 5-7 contained S/N from A. niger cultured with willow. Differences in banding pattern were observed between the $\mathrm{S} / \mathrm{Ns}$ from A. niger cultured with either straw or willow. Lanes 2-7 have S/N from independent shake-flask cultures.

Additional file 4: Time course of saccharification of willow and wheat straw using concentrated culture supernatant. An equal amount of protein from concentrated S/Ns from A. niger cultured with either straw or willow was used to saccharify straw or willow substrates for different lengths of time. The reducing end groups were quantified with the DNS assay. The reducing end groups released by equal amounts of protein from the different culture S/Ns from reactions incubated for various lengths of time are expressed per $\mathrm{mg}$ of the lignocellulosic substrate in the saccharification assay. The results are from an assay from the S/Ns from one of the pooled duplicate cultures with either lignocellulosic substrate. The purpose of this time-course was to determine an appropriate incubation time for subsequent experiments and $24 \mathrm{~h}$ was chosen.

\section{Additional file 5: Free sugars in the willow media before} inoculation with $A$. niger and in the willow culture supernatants incubated with $A$. niger. The free sugars in the willow media and from the culture supernatants were measured using HPLC. The sugar concentration from the willow media (autoclaved) is from a single preparation of the willow media and the sugar concentrations from the culture supernatants ( $3 \mathrm{~h} \mathrm{~A}$. niger to $24 \mathrm{~h} \mathrm{~A}$. niger) are from triplicate shake flask cultures. Error bars represent standard errors.

Additional file 6: Table with primer sequences used in this study. Additional file 7: Table with list of which genes were assigned to particular enzyme activities for use in Figures 1 and 2.

\section{Abbreviations}

qRT-PCR: Quantitative reverse transcriptase/real-time PCR; $p$ : $p$-value from DESeq analysis adjusted for multiple hypothesis testing; S/N: Supernatant; MWCO: Molecular weight cut-off.

\section{Competing interests}

The authors declare that they have no competing interests.

\section{Authors' contributions}

STP, SD, GAT and DBA conceived the study. STP, PD, SD, MK \& AN carried out all culture work, RNA extractions and enzymatic assays. RI, SG \& GAT provided lignocellulosic substrates and performed analysis. RW carried out RNA-sequencing. MJB provided sequence alignments and statistical analysis. STP, PD, SD, JMvM \& DBA analysed the data. STP, PD \& DBA wrote the manuscript. All authors read and approved the final manuscript.

\section{Acknowledgements}

The authors acknowledge funding from the Biotechnology and Biological Sciences Research Council (BBSRC) Sustainable Bioenergy Centre (BSBEC) under the programme Lignocellulosic Conversion to Ethanol (LACE) (Grant BB/G01616X/1), Lee Shunburne for excellent technical support and Dr. Sarah Purdy for the willow substrate.

\section{Author details}

'School of Life Sciences, University of Nottingham, University Park, Nottingham NG7 2RD, UK. ${ }^{2}$ School of Biosciences, University of Nottingham, Sutton Bonington Campus, Loughborough LE12 5RD, UK. ${ }^{3}$ Deep Seq, Faculty of Medicine and Health Sciences, Queen's Medical Centre, University of Nottingham, Nottingham NG7 2UH, UK. ${ }^{4}$ Current Address: Microbiology Services, Public Health England, Salisbury, UK. ${ }^{5}$ Current Address: Sorbonne Universités, UPMC Univ Paris 06, IBPS UMR 7138, Evolution Paris-Seine, F-75005 Paris, France.

Received: 10 March 2014 Accepted: 7 August 2014

Published online: 17 November 2014

\section{References}

1. Gomez LD, Steele-King CG, McQueen-Mason SJ: Sustainable liquid biofuels from biomass: the writing's on the walls. New Phytol 2008, 178:473-485.

2. Tian C, Beeson WT, lavarone AT, Sun J, Marletta MA, Cate JHD, Glass NL: Systems analysis of plant cell wall degradation by the model filamentous fungus Neurospora crassa. Proc Natl Acad Sci U S A 2009, 106:22157-22162.

3. Häkkinen M, Arvas M, Oja M, Aro N, Penttilä M, Saloheimo M, Pakula TM: Re-annotation of the CAZy genes of Trichoderma reesei and transcription in the presence of lignocellulosic substrates. Microb Cell Fact 2012, 11:134.

4. Bischof R, Fourtis L, Limbeck A, Gamauf C, Seiboth B, Kubicek CP: Comparative analysis of the Trichoderma reesei transcriptome during growth on the cellulase inducing substrates wheat straw and lactose. Biotechnol Biofuels 2013, 6:127.

5. Delmas S, Pullan ST, Gaddipati S, Kokolski M, Malla S, Blythe MJ, Ibbett R, Campbell M, Liddell S, Aboobaker A, Tucker GA, Archer DB: Uncovering the genome-wide transcriptional responses of the filamentous fungus Aspergillus niger to lignocellulose using RNA sequencing. PLoS Genet 2012, 8:e1002875.

6. Scheller HV, Ulvskov P: Hemicelluloses. Annu Rev Plant Biol 2010, 61:263-289.

7. Schmoll M: The information highways of a biotechnological workhorsesignal transduction in Hypocrea jecorina. BMC Genomics 2008, 9:430.

8. Herold S, Bischof R, Metz B, Seiboth B, Kubicek CP: Xylanase gene transcription in Trichoderma reesei is triggered by different inducers representing different hemicellulosic pentose polymers. Eukaryot Cell 2013, 12:390-398.

9. Karp A, Shield I: Bioenergy from plants and the sustainable yield challenge. New Phytol 2008, 179:15-32.

10. Pel HJ, de Winde JH, Archer DB, Dyer PS, Hofmann G, Schaap PJ, Turner G, de Vries RP, Albang R, Albermann K, Andersen MR, Bendtsen JD, Benen JAE, van den Berg M, Breestraat S, Caddick MX, Contreras R, Cornell M, Coutinho PM, Danchin EGJ, Debets AJM, Dekker P, van Dijck PWM, van Dijk A, Dijkhuizen L, Driessen AJM, d'Enfert C, Geysens S, Goosen C, Groot GSP, et al: Genome sequencing and analysis of the versatile cell factory Aspergillus niger CBS 513.88. Nat Biotechnol 2007, 25:221-231.

11. Andersen MR, Giese M, de Vries RP, Nielsen J: Mapping the polysaccharide degradation potential of Aspergillus niger. BMC Genomics 2012, 13:313. 
12. Mortazavi A, Williams BA, McCue K, Schaeffer L, Wold B: Mapping and quantifying mammalian transcriptomes by RNA-Seq. Nat Methods 2008, 5:621-628.

13. Ries L, Pullan ST, Delmas S, Malla S, Blythe MJ, Archer DB: Genome-wide transcriptional response of Trichoderma reesei to lignocellulose using RNA sequencing and comparison with Aspergillus niger. BMC Genomics 2013, 14:541.

14. Van Munster JM, Daly P, Delmas S, Pullan ST, Blythe MJ, Malla S, Kokolski M, Noltorp ECM, Wennberg K, Fetherston R, Beniston R, Yu X, Dupree P, Archer $D B$ : The role of carbon starvation in the induction of enzymes that degrade plant-derived carbohydrates in Aspergillus niger. Fungal Genet Biol 2014, (in press).

15. Cantarel BL, Coutinho PM, Rancurel C, Bernard T, Lombard V, Henrissat B: The Carbohydrate-Active EnZymes database (CAZy): an expert resource for Glycogenomics. Nucleic Acids Res 2009, 37(Database issue):D233-D238.

16. Lombard V, Golaconda Ramulu H, Drula E, Coutinho PM, Henrissat B: The carbohydrate-active enzymes database (CAZy) in 2013. Nucleic Acids Res 2013, 42:D490-D495.

17. Aspeborg H, Coutinho PM, Wang Y, Brumer H, Henrissat B: Evolution, substrate specificity and subfamily classification of glycoside hydrolase family 5 (GH5). BMC Evol Biol 2012, 12:186.

18. Master ER, Zheng Y, Storms R, Tsang A, Powlowski J: A xyloglucan-specific family 12 glycosyl hydrolase from Aspergillus niger: recombinant expression, purification and characterization. Biochem J 2008, 411:161-170.

19. Pauly M, Andersen LN, Kauppinen S, Kofod LV, York WS, Albersheim P, Darvill A: A xyloglucan-specific endo-beta-1,4-glucanase from Aspergillus aculeatus: expression cloning in yeast, purification and characterization of the recombinant enzyme. Glycobiology 1999, 9:93-100.

20. Levasseur A, Drula E, Lombard V, Coutinho PM, Henrissat B: Expansion of the enzymatic repertoire of the CAZy database to integrate auxiliary redox enzymes. Biotechnol Biofuels 2013, 6:41.

21. Quinlan RJ, Sweeney MD, Lo Leggio L, Otten H, Poulsen J-CN, Johansen KS, Krogh KBRM, Jørgensen Cl, Tovborg M, Anthonsen A, Tryfona T, Walter CP, Dupree P, Xu F, Davies GJ, Walton PH: Insights into the oxidative degradation of cellulose by a copper metalloenzyme that exploits biomass components. Proc Natl Acad Sci U S A 2011, 108:15079-15084.

22. Beeson WT, Phillips CM, Cate JHD, Marletta MA: Oxidative cleavage of cellulose by fungal copper-dependent polysaccharide monooxygenases. J Am Chem Soc 2012, 134:890-892.

23. Christov LP, Prior BA: Esterases of xylan-degrading microorganisms: production, properties, and significance. Enzyme Microb Technol 1993, 15:460-475.

24. Bauer S, Vasu P, Persson S, Mort AJ, Somerville CR: Development and application of a suite of polysaccharide-degrading enzymes for analyzing plant cell walls. Proc Natl Acad Sci U S A 2006, 103:11417-11422.

25. Gielkens MM, Visser J, de Graaff LH: Arabinoxylan degradation by fungi: characterization of the arabinoxylan-arabinofuranohydrolase encoding genes from Aspergillus niger and Aspergillus tubingensis. Curr Genet 1997, 31:22-29.

26. De Souza WR, Maitan-Alfenas GP, de Gouvêa PF, Brown NA, Savoldi M, Battaglia E, Goldman MHS, de Vries RP, Goldman GH: The influence of Aspergillus niger transcription factors AraR and $X \ln R$ in the gene expression during growth in D-xylose, L-arabinose and steam-exploded sugarcane bagasse. Fungal Genet Biol 2013, 60:29-45.

27. Battaglia E, Hansen SF, Leendertse A, Madrid S, Mulder H, Nikolaev I, de Vries RP: Regulation of pentose utilisation by AraR, but not XInR, differs in Aspergillus nidulans and Aspergillus niger. Appl Microbiol Biotechnol 2011, 91:387-397.

28. De O, Buanafina MM: Feruloylation in grasses: current and future perspectives. Mol Plant 2009, 2:861-872.

29. Vogel J: Unique aspects of the grass cell wall. Curr Opin Plant Biol 2008 11:301-307.

30. De Vries RP, Michelsen B, Poulsen $\mathrm{CH}$, Kroon PA, van den Heuvel RH, Faulds CB, Williamson G, van den Hombergh JP, Visser J: The faeA genes from Aspergillus niger and Aspergillus tubingensis encode ferulic acid esterases involved in degradation of complex cell wall polysaccharides. Appl Environ Microbiol 1997, 63:4638-4644.

31. De Vries RP, Visser J: Regulation of the feruloyl esterase (faeA) gene from Aspergillus niger. Appl Environ Microbiol 1999, 65:5500-5503.

32. De Vries RP, VanKuyk PA, Kester HCM, Visser J: The Aspergillus niger faeB gene encodes a second feruloyl esterase involved in pectin and xylan degradation and is specifically induced in the presence of aromatic compounds. Biochem J 2002, 363(Pt 2):377-386
33. Miller GL: Use of dinitrosalicylic acid reagent for determination of reducing sugar. Anal Chem 1959, 31:426-428.

34. Couturier M, Navarro D, Olivé C, Chevret D, Haon M, Favel A, Lesage-Meessen L, Henrissat B, Coutinho PM, Berrin J-G: Post-genomic analyses of fungal lignocellulosic biomass degradation reveal the unexpected potential of the plant pathogen Ustilago maydis. BMC Genomics 2012, 13:57.

35. Ohtaki S, Maeda H, Takahashi T, Yamagata Y, Hasegawa F, Gomi K, Nakajima $\mathrm{T}$, Abe K: Novel hydrophobic surface binding protein, $\mathrm{HsbA}$, produced by Aspergillus oryzae. Appl Environ Microbiol 2006, 72:2407-2413.

36. DeZwaan TM, Carroll AM, Valent B, Sweigard JA: Magnaporthe grisea pth $11 \mathrm{p}$ is a novel plasma membrane protein that mediates appressorium differentiation in response to inductive substrate cues. Plant Cell 1999, 11:2013-2030.

37. Takahashi T, Maeda H, Yoneda S, Ohtaki S, Yamagata Y, Hasegawa F, Gomi K, Nakajima T, Abe K: The fungal hydrophobin RolA recruits polyesterase and laterally moves on hydrophobic surfaces. Mol Microbiol 2005, 57:1780-1796.

38. Saeman JF, Moore WE, Mitchell RL, Millett MA: Techniques for the determination of pulp constituents by quantitiative paper chromatography. Tech Assoc Pulp Pap Ind 1954, 37:336-343.

39. Fukushima RS, Hatfield RD: Extraction and isolation of lignin for utilization as a standard to determine lignin concentration using the acetyl bromide spectrophotometric method. J Agric Food Chem 2001, 49:3133-3139.

40. Bos CJ, Debets AJ, Swart K, Huybers A, Kobus G, Slakhorst SM: Genetic analysis and the construction of master strains for assignment of genes to six linkage groups in Aspergillus niger. Curr Genet 1988, 14:437-443.

41. Novodvorska M, Hayer K, Pullan ST, Wilson R, Blythe MJ, Stam H, Stratford M, Archer DB: Trancriptional landscape of Aspergillus niger at breaking of conidial dormancy revealed by RNA-sequencing. BMC Genomics 2013, 14:246.

42. Anders S, Huber W: Differential expression analysis for sequence count data. Genome Biol 2010, 11:R106.

43. Barrett T, Wilhite SE, Ledoux P, Evangelista C, Kim IF, Tomashevsky M, Marshall KA, Phillippy KH, Sherman PM, Holko M, Yefanov A, Lee H, Zhang N, Robertson CL, Serova N, Davis S, Soboleva A: NCBI GEO: archive for functional genomics data sets-update. Nucleic Acids Res 2013, 41(Database issue):D991-D995.

44. Cerqueira GC, Arnaud MB, Inglis DO, Skrzypek MS, Binkley G, Simison M, Miyasato SR, Binkley J, Orvis J, Shah P, Wymore F, Sherlock G, Wortman JR: The Aspergillus genome database: multispecies curation and incorporation of RNA-Seq data to improve structural gene annotations. Nucleic Acids Res 2014, 42(Database issue):D705-D710.

45. Van den Brink J, de Vries RP: Fungal enzyme sets for plant polysaccharide degradation. Appl Microbiol Biotechnol 2011, 91:1477-1492.

46. Yan JX, Wait R, Berkelman T, Harry RA, Westbrook JA, Wheeler CH, Dunn MJ: A modified silver staining protocol for visualization of proteins compatible with matrix-assisted laser desorption/ionization and electrospray ionization-mass spectrometry. Electrophoresis 2000, 21:3666-3672.

doi:10.1186/s40694-014-0003-x

Cite this article as: Pullan et al:: RNA-sequencing reveals the complexities of the transcriptional response to lignocellulosic biofuel substrates in Aspergillus niger. Fungal Biology and Biotechnology 2014 1:3.

\section{Submit your next manuscript to BioMed Central and take full advantage of:}

- Convenient online submission

- Thorough peer review

- No space constraints or color figure charges

- Immediate publication on acceptance

- Inclusion in PubMed, CAS, Scopus and Google Scholar

- Research which is freely available for redistribution 